\title{
Effects of alfalfa and alfalfa-grass mixtures with nitrogen fertilization on dry matter yield and forage nutritive value
}

\author{
Iryna McDonald, Rudra Baral* and Doohong Min \\ Department of Agronomy, Kansas State University, Manhattan, KS 66506, USA
}

Received: Oct 7, 2020

Revised: Dec 12, 2020

Accepted: Dec 21, 2020

*Corresponding author

Rudra Baral

Department of Agronomy, Kansas State University, Manhattan, KS 66506, USA.

Tel: +1-785-532-2292

E-mail: rudrabaral@ksu.edu

Copyright $@ 2021$ Korean Society of Animal Sciences and Technology. This is an Open Access article distributed under the terms of the Creative Commons Attribution Non-Commercial License (http:// creativecommons.org/licenses/by$\mathrm{nc} / 4.0 /$ ) which permits unrestricted non-commercial use, distribution, and reproduction in any medium, provided the original work is properly cited.

\section{ORCID}

Iryna McDonald

https://orcid.org/0000-0002-4515-3305

Rudra Baral

https://orcid.org/0000-0002-9018-9470

Doohong Min

https://orcid.org/0000-0002-9404-5175

Competing interests

No potential conflict of interest relevant to this article was reported.

Funding sources

This research was funded by the Department of Agronomy, Kansas State University.

Acknowledgements Not applicable.

Availability of data and material Upon reasonable request, the datasets of this study can be available from the

\begin{abstract}
Alfalfa (Medicago sativa L.) is an important forage legume grown in Kansas, USA and its productivity with cool-season grasses however is unknown. The objective of this study was to determine the dry matter yield (DMY) and forage nutritive value of alfalfa-grass mixtures compared to those of alfalfa and grasses grown in monoculture with and without nitrogen fertilization. Three different alfalfa varieties were planted (reduced-lignin alfalfa, Roundup Ready, and conventional alfalfa) and two kinds of cool-season grasses (smooth brome, Bromus inermis Leyss, and tall fescue, Festuca arundinacea Schreb) were planted as a monoculture or in alfalfa-grass mixtures. Nitrogen fertilizer (urea) was applied at green-up at a rate of $56 \mathrm{~kg} / \mathrm{ha}$ and after the second cutting at a rate of $56 \mathrm{~kg} / \mathrm{ha}$ in 2016 and 2017, respectively. and control treatments received no nitrogen. DMY was significantly higher in monoculture alfalfa and alfalfa-grass mixtures than in grass monocultures. Between alfalfa monoculture and alfalfa-grass mixtures, no significant differences in DMY were found. For all treatments, nitrogen application significantly increased DMY compared to the control. In 2016 and 2017, the low-lignin alfalfa monoculture had the lowest acid detergent fiber (ADF) and the grass monocultures had the highest ADF. In 2016 and 2017, neutral detergent fiber (NDF) in smooth bromegrass and tall fescue was higher than in other species treatments. A low-lignin alfalfa monoculture had significantly lower NDF concentration compared to alfalfa-grass mixtures. When averaged over 2016 and 2017, relative feed value (RFV) was highest in low-lignin alfalfa and lowest in the grass monocultures. In both years, nitrogen fertilizer application did not affect nutritive values.

Keywords: Dry matter yield, Forage nutritive value, Alfalfa, Tall fescue, Smooth bromegrass, Nitrogen application
\end{abstract}

\section{INTRODUCTION}

Alfalfa (Medicago sativa L.) is a perennial legume that is important in forage production worldwide due to its high forage nutritive value and dry matter yield (DMY) [1-3]. Legumes benefit grass pastures not only by transferring fixed nitrogen to the grasses [4-6] but also by providing biomass to the total yield of a pasture. This is important during the middle of the summer when grasses grow better with 
corresponding author.

Authors' contributions

Conceptualization: Min D.

Data curation: McDonald I.

Formal analysis: McDonald I, Baral R.

Methodology: McDonald I, Min D.

Software: Baral R.

Validation: Min D, Baral R

Investigation: McDonald I.

Writing - original draft: McDonald I.

Writing - review \& editing: Baral R, Min D.

Ethics approval and consent to participate This article does not require IRB/IACUC approval because there are no human and animal participants. alfalfa and can provide additional forage to animals $[7,8]$.

Farmers often plant grasses in pastures, because they can control weeds and improve grazing conditions $[9,10]$. Also, planting legumes with grasses helps improve forage nutritive value and increases DMY of pastures compared to pastures with pure grasses [11]. Because legume crops can provide nitrogen to the grasses, Woodfield and Clark [12] recommended that farmers use a new strategy in farming and plant legumes with grasses. Legume-grass mixtures are not as easy to manage as monoculture grasslands, because the legumes and grasses compete for water, nutrients, and light $[11,13-15]$. However, much research has shown that the potential advantages of legumegrass mixtures can outweigh the disadvantages. It would be of interest to list a few of the agronomic or animal nutrition advantages to having important cool-season forage grasses in mixture with alfalfa.

Tracy et al. [16] showed that yields of pastures with grasses mixed with alfalfa were almost identical to yields of pastures with only grasses that were fertilized with urea nitrogen. Sengul [17] found that DMY of legume-grass mixtures, both with and without fertilizer, was higher than DMY of grass monocultures. Planting legumes with grasses can supply the grasses with $>80 \%$ of the nitrogen that they need through nitrogen fixation $[4,18]$. Grasses in the spring react positively to available nitrogen in the soil, and usually, nitrogen in fertilizer or manure is applied to grasses in the spring. Legumes fix little nitrogen in early spring, because of low temperatures [19]. Therefore, it is recommended that nitrogen fertilizer be applied to legume-grass mixtures in the early spring, which increases the biomass of grasses at that time [20-22].

The importance of forage nutritive value cannot be over-emphasized as far as the sustainability and profitability of any farm are concerned. It is essential for sufficient animal nutrition, so the animals can have high gain rates, ample production of milk, and efficient production. Immense variations in the quality of forage within and among forage crops occur, just as is the case for variations in nutritional needs within and among animal classes and species [23]. Forage nutritive value is directly related to the content and availability of essential nutrients for the consuming animals and is defined by three processes, which are the capacity of the animal to consume, assimilate (availability), and digest (digestibility) the essential nutrients in the feed [24]. Various factors affect the nutritive value of forage. In the same or different years, similar plants can have varying nutritive value, even when each has been planted in the same field. Grass-legume mixtures are acknowledged to have higher crude protein concentrations, as well as lower fiber concentrations, compared to pure grass stands [23]. Brown et al. [25] observed that in grass-mixtures crude protein increases, as well as DMY. Forage nutritive value is affected by fertilization, where the fertilization of grasses using nitrogen usually results in a substantial increase in yield, while also generally increasing crude protein levels.

Little research on legume-grass mixtures has been done in Kansas, USA since late 1970s. Therefore, the objectives of this study were to evaluate the productivity of alfalfa-grass mixtures compared alfalfa in monoculture and grasses in monoculture and to assess the effect of nitrogen fertilizer on forage DMY and nutritive value of the monocultures of alfalfa and grasses and alfalfagrass mixtures.

\section{MATERIALS AND METHODS}

\section{Study site}

The experiment was conducted at the Ashland Bottoms Research Farm of Kansas State University $\left(39^{\circ} 14^{\prime} \mathrm{N}, 96^{\circ} 64^{\prime} \mathrm{W}\right)$ between April 2015 and December 2017. The soil type at the study site was a Belvue silt loam [26]. A soil test, done at the Soil Testing Laboratory at Kansas State University, 
showed that the study field had a $\mathrm{pH}$ of 6.96 and an organic matter content of $2 \%$. Weather data were collected from an automated Kansas Mesonet Station located at the Ashland Bottoms Research Farm (Table 1).

Three different alfalfa varieties were planted: 'Hi-Gest $360 \mathrm{LL}$,' a reduced-lignin variety; 'RR Tonica,' a Roundup Ready variety, and 'Gunner,' a conventional alfalfa variety. Two kinds of coolseason grasses, smooth bromegrass and tall fescue were planted as monoculture crops and in the legume-grass mixtures as binary and trio mixtures. This resulted in 14 different treatments (Table 2). All 14 treatments then were treated with nitrogen to provide 28 treatments in total: 14 with nitrogen and 14 without nitrogen. The treatments without nitrogen were called the controls. Nitrogen was applied as urea at a rate of $56 \mathrm{~kg} / \mathrm{ha}$ after planting on April 24, 2015 and at the

Table 1. Rainfall and maximum and minimum temperatures at Ashland Bottoms Research Farm, Kansas State University during the study period

\begin{tabular}{|c|c|c|c|c|c|c|c|c|c|c|c|c|}
\hline \multirow{2}{*}{$\begin{array}{c}\text { Climate } \\
\text { characteristics }\end{array}$} & \multicolumn{12}{|c|}{ Month } \\
\hline & Jan & Feb & Mar & Apr & May & Jun & Jul & Aug & Sep & Oct & Nov & Dec \\
\hline \multicolumn{13}{|l|}{2015} \\
\hline Monthly rain (mm) & & & & 67.57 & 218.68 & 107.2 & 128 & 81 & 104.9 & 15.49 & 110.5 & 82.8 \\
\hline Mean Max. temp. $\left({ }^{\circ} \mathrm{C}\right)$ & & & & 20.6 & 22.95 & 31.08 & 31.93 & 30.4 & 29.68 & 22.42 & 16.22 & 9.36 \\
\hline Mean Min. temp. $\left({ }^{\circ} \mathrm{C}\right)$ & & & & 7.26 & 12.25 & 18.64 & 20.78 & 17.23 & 16.96 & 7.62 & 2.87 & -1.96 \\
\hline \multicolumn{13}{|l|}{2016} \\
\hline Monthly rain (mm) & 12.7 & 10.16 & 11.17 & 214.6 & 177.3 & 39.36 & 155 & 185.7 & 105.7 & 70.36 & 7.62 & 21.08 \\
\hline Mean Max. temp. $\left({ }^{\circ} \mathrm{C}\right)$ & 4.5 & 11.8 & 18.2 & 21.32 & 23.73 & 33.45 & 32.35 & 30.37 & 28.45 & 24.26 & 17.39 & 5.6 \\
\hline Mean Min. temp. $\left({ }^{\circ} \mathrm{C}\right)$ & -6.1 & -2.97 & 2.37 & 7.66 & 11.26 & 19.48 & 21.24 & 19.61 & 16.02 & 9.42 & 3.53 & -7.14 \\
\hline \multicolumn{13}{|l|}{2017} \\
\hline Monthly rain (mm) & 24.89 & 11.94 & 106.9 & 126.8 & 96.76 & 71.63 & 33.78 & 154.7 & 20.58 & 92.96 & 2.28 & 2.79 \\
\hline Mean Max. temp. $\left({ }^{\circ} \mathrm{C}\right)$ & 6.44 & 13.42 & 15.45 & 19.42 & 24.67 & 30.96 & 33.37 & 28.55 & 29.11 & 21.23 & 14.14 & 6.36 \\
\hline Mean Min. temp. $\left({ }^{\circ} \mathrm{C}\right)$ & -5.13 & -1.05 & 2.63 & 7.58 & 11.15 & 17.2 & 20.5 & 15.98 & 15.01 & 7.22 & 0.7 & -5.38 \\
\hline \multicolumn{13}{|c|}{30 years (1987-2017) average } \\
\hline Monthly rain (mm) & 16.54 & 27.78 & 57.45 & 83.94 & 121.42 & 136.32 & 112.26 & 108.20 & 83.00 & 61.51 & 38.63 & 27.28 \\
\hline Mean Max. temp. $\left({ }^{\circ} \mathrm{C}\right)$ & 5.45 & 8.29 & 14.68 & 20.34 & 25.24 & 30.58 & 33.31 & 32.50 & 28.06 & 21.55 & 13.39 & 6.62 \\
\hline Mean Min. temp. $\left({ }^{\circ} \mathrm{C}\right)$ & -7.27 & -5.44 & -0.16 & 5.81 & 11.61 & 17.14 & 19.87 & 18.57 & 13.21 & 6.50 & -0.18 & -5.78 \\
\hline
\end{tabular}

Table 2. Composition of alfalfa and grasses as monocultures and legume-grass mixtures

\begin{tabular}{lll}
\hline Treatment & \multicolumn{1}{c}{ Species } & Abbreviation \\
\hline 1 & Gunner conventional alfalfa & A \\
2 & Low-lignin Hi-Gest 360 LL alfalfa & LLA \\
3 & Roundup ready RR tonica alfalfa & RRA \\
4 & Smooth bromegrass & SB \\
5 & Tall fescue & TF \\
6 & Gunner conventional alfalfa + smooth bromegrass & A + SB \\
7 & Gunner conventional alfalfa + tall fescue & A + TF \\
8 & Low-lignin Hi-Gest 360 LL alfalfa + smooth bromegrass & LLA + SB \\
9 & Low-lignin Hi-Gest 360 LL alfalfa + tall fescue & LLA + TF \\
10 & Roundup ready RR tonica alfalfa + smooth bromegrass & RRA + SB \\
11 & Roundup ready RR tonica alfalfa + tall fescue & RRA + TF \\
12 & Gunner conventional alfalfa + smooth bromegrass + tall fescue & A + SB + TF \\
13 & Low-lignin Hi-Gest 360 LL alfalfa + smooth bromegrass + tall fescue & LLA + SB + TF \\
14 & Roundup ready RR Tonica alfalfa + smooth bromegrass + tall fescue & RRA + SB + TF \\
\hline
\end{tabular}


green up and after the second cutting in 2016 and 2017. In monocultures, the seeding rates were as follows: alfalfa variety, $20.18 \mathrm{~kg} / \mathrm{h}$; tall fescue, $13.45 \mathrm{~kg} / \mathrm{ha}$; and smooth bromegrass, $16.81 \mathrm{~kg} / \mathrm{ha}$. In binary mixtures, seeding rates were as follows: alfalfa variety, $11.21 \mathrm{~kg} / \mathrm{ha}$; tall fescue, $8.97 \mathrm{~kg} / \mathrm{ha}$, and smooth bromegrass, $11.21 \mathrm{~kg} / \mathrm{ha}$. In trio mixtures, an alfalfa variety, smooth bromegrass, and tall fescue all had a seeding rate of $7.85 \mathrm{~kg} / \mathrm{ha}$. During the establishment year, the favorable growing conditions have led to a high weed population, and due to this the first cut in 2015 was controlled by mowing the study field completely, and after that, the weed population was controlled by handweeding.

The experimental design was a split-plot (with or without nitrogen) in a randomized complete block design with four replications. There were 28 treatments of two nitrogen application rates as whole plots and mixture treatments as subplots. Nitrogen was applied as urea at a rate of $56 \mathrm{~kg} / \mathrm{ha}$ after planting on April 24, 2015 and $56 \mathrm{~kg} / \mathrm{ha}$ at the green up and $56 \mathrm{~kg} / \mathrm{ha}$ after the second cutting in 2016 and 2017. Plot size was 1 meter wide and 6 meters long, for a total of 112 plots. In 2016, plots were harvested on 19 May, 22 June, 27 July, and 3 September; in 2017, they were harvested on 24 May, 26 June, 28 July, and 1 September. In both years, plots were harvested when alfalfa reached 1/10th bloom stage.

Because smooth bromegrass and tall fescue are cool-season grasses, they recovered poorly from the second cut in 2016 and first cut in 2017, and this led to slow regrowth and DMY. Therefore, the plots with pure grasses were not harvested in the third cut in 2016 and second cut in 2017.

\section{Dry matter yield}

Sub-samples were collected, placed into paper bags, and put in a cooler; bags were taken out of the cooler, weighed, and placed in a custom-built forage dryer made by the Agronomy Farm Shop at Kansas State University at $60^{\circ} \mathrm{C}$ for $72 \mathrm{~h}$. After drying, samples were weighted again and the dry matter per unit area was calculated, Then, the calculated dry matter per unit area was converted to DMY per hectare $(\mathrm{Mg} / \mathrm{ha})$.

\section{Forage nutritive value}

The dry samples were ground in a Wiley mill with a 0.04 inches screen. The total nitrogen in the samples was determined by the Soil Testing Laboratory at Kansas State University. The laboratory digests the samples using a sulfuric peroxide acid digestion, and then the digest is analyzed for nitrogen by a colorimetric procedure using the Rapid Flow Analyzer (Model RFA-300) and RFA Methodology No. A303-S072 from Alpkem (Clackamas, OR, USA). Crude protein (CP) in percent was calculated by multiplying the total nitrogen (\%) by 6.25 . Following the protocol of ANKOM Technology (Macedon, NY, USA), the acid detergent fiber (ADF) and neutral detergent fiber (NDF) were analyzed using ANKOM method.

Relative feed value (RFV) is calculated from digestible dry matter digestibility (DMD) and dry matter intake (DMI) using ADF (\%) and NDF (\%), respectively [27]. Using the equations of Rohweder et al. [27], the RFV of legume-grass mixtures and monocultures was calculated as follows:

$$
\begin{gathered}
\mathrm{DMD}(\%)=88.9-(0.779 \times \mathrm{ADF}) \\
\mathrm{DMI}(\%)=120 /(\mathrm{NDF}) \\
\mathrm{RFV}=(\mathrm{DMD} \times \mathrm{DMI}) / 1.29
\end{gathered}
$$

\section{Statistical analysis}

Differences in DMY and forage nutritive value were evaluated by ANOVA using PROC 
GLIMMIX (SAS, 2011). The ANOVA for these variables was conducted for each year, and for each cut, with 14 combinations of varieties as a fixed effect. Block was a random effect, and all data were checked for normality and homogeneity of variance. Mean separation was performed using the Bonferroni correction $[28,29]$. All statistical comparisons were made at the significance level of $\alpha=0.05$.

\section{RESULTS AND DISCUSSION}

\section{Dry matter yield}

The means and total of DMY are shown in Table 3. There was no interaction between species mixture treatments and nitrogen fertilizer application in all cuts of both years for DMY.

The DMY of the first cut in 2016 was significantly higher in alfalfa monocultures and alfalfagrass mixtures than in the monocultures of two cool-season grasses. No difference in DMY was found in three different alfalfa varieties, two cool-season grasses monocultures, and alfalfagrass mixtures, respectively. DMY with nitrogen application was significantly higher than the control (DMY with $\mathrm{N}$ application: $5.3 \mathrm{Mg} / \mathrm{ha}$ and control: $4.8 \mathrm{Mg} / \mathrm{ha}$ ) indicating that nitrogen fertilization appears to be a desirable practice in increasing DMY in this study. The DMY of the second cut in 2016 was significantly higher in alfalfa monoculture and legume-grass mixtures than in monocultures of two grasses. The yield difference between monoculture grasses and other species treatments was greater in the second cutting than the first cutting. This might be due to increasing air temperature and a lot lower precipitation after first cutting until second cutting. The DMY with nitrogen application was significantly higher than without (DMY with $\mathrm{N}$ application: $5.2 \mathrm{Mg} / \mathrm{ha}$

Table 3. Mean and total dry matter yield (Mg/ha) in 2016 and 2017

\begin{tabular}{|c|c|c|c|c|c|c|c|c|c|c|}
\hline \multirow{2}{*}{ Treatments } & \multicolumn{5}{|c|}{2016} & \multicolumn{5}{|c|}{2017} \\
\hline & Cut 1 & Cut 2 & Cut 3 & Cut 4 & Total & Cut1 & Cut 2 & Cut 3 & Cut 4 & Total \\
\hline No & $4.8^{\mathrm{b} 1)}$ & $4.7^{b}$ & $4.8^{a}$ & $3.7^{b}$ & $18.0^{b}$ & $5.0^{\mathrm{a}}$ & $5.3^{\mathrm{a}}$ & $4.7^{b}$ & $3.9^{\mathrm{a}}$ & $18.9^{b}$ \\
\hline N 112 & $5.3^{\mathrm{a}}$ & $5.2^{\mathrm{a}}$ & $4.8^{\mathrm{a}}$ & $3.9^{a}$ & $19.2^{\mathrm{a}}$ & $5.5^{\mathrm{a}}$ & $5.3^{\mathrm{a}}$ & $5.0^{\mathrm{a}}$ & $4.0^{\mathrm{a}}$ & $19.8^{\mathrm{a}}$ \\
\hline A & $5.3^{\mathrm{a}}$ & $5.1^{\mathrm{a}}$ & $4.9^{\mathrm{a}}$ & $3.5^{\mathrm{ab}}$ & $18.8^{\mathrm{a}}$ & $5.1^{\mathrm{ab}}$ & $5.2^{\mathrm{a}}$ & $4.8^{\mathrm{ab}}$ & $4.1^{\mathrm{ab}}$ & $19.2^{\mathrm{a}}$ \\
\hline LLA & $4.9^{\mathrm{a}}$ & $5.3^{\mathrm{a}}$ & $4.7^{\mathrm{a}}$ & $3.9^{\mathrm{ab}}$ & $18.8^{\mathrm{a}}$ & $5.1^{\mathrm{ab}}$ & $5.0^{\mathrm{a}}$ & $4.8^{\mathrm{ab}}$ & $4.1^{\mathrm{ab}}$ & $19.0^{\mathrm{a}}$ \\
\hline RRA & $5.0^{\mathrm{a}}$ & $5.7^{\mathrm{a}}$ & $5.1^{\mathrm{a}}$ & $3.7^{\mathrm{ab}}$ & $19.5^{\mathrm{a}}$ & $4.5^{\mathrm{ab}}$ & $5.4^{\mathrm{a}}$ & $5.0^{\mathrm{a}}$ & $4.2^{\mathrm{a}}$ & $19.1^{a}$ \\
\hline SB & $2.5^{b}$ & $1.3^{b}$ & $\mathrm{~N} / \mathrm{A}$ & $4.6^{\mathrm{a}}$ & $8.4^{\mathrm{b}}$ & $3.5^{\mathrm{b}}$ & $\mathrm{N} / \mathrm{A}$ & $3.9^{b}$ & $2.8^{c}$ & $10.2^{b}$ \\
\hline TF & $2.3^{b}$ & $1.9^{b}$ & N/A & $4.3^{\mathrm{ab}}$ & $8.5^{\mathrm{b}}$ & $4.4^{\mathrm{ab}}$ & $N / A$ & $4.5^{\mathrm{ab}}$ & $3.4^{\mathrm{bc}}$ & $12.3^{b}$ \\
\hline$A+S B$ & $5.5^{\mathrm{a}}$ & $5.5^{\mathrm{a}}$ & $5.0^{\mathrm{a}}$ & $3.6^{\mathrm{ab}}$ & $19.6^{\mathrm{a}}$ & $5.6^{\mathrm{ab}}$ & $5.5^{\mathrm{a}}$ & $5.1^{a}$ & $4.2^{\mathrm{a}}$ & $20.4^{\mathrm{a}}$ \\
\hline$A+T F$ & $5.7^{\mathrm{a}}$ & $5.5^{\mathrm{a}}$ & $4.8^{\mathrm{a}}$ & $3.7^{\mathrm{ab}}$ & $19.7^{\mathrm{a}}$ & $5.6^{\mathrm{ab}}$ & $5.4^{\mathrm{a}}$ & $5.0^{\mathrm{a}}$ & $4.2^{\mathrm{a}}$ & $20.2^{a}$ \\
\hline$L L A+S B$ & $5.4^{\mathrm{a}}$ & $5.3^{\mathrm{a}}$ & $4.6^{a}$ & $3.8^{\mathrm{ab}}$ & $19.1^{\mathrm{a}}$ & $5.8^{\mathrm{a}}$ & $4.8^{\mathrm{a}}$ & $4.9^{\mathrm{ab}}$ & $4.3^{\mathrm{a}}$ & $19.8^{a}$ \\
\hline $\mathrm{LLA}+\mathrm{TF}$ & $5.7^{\mathrm{a}}$ & $5.6^{\mathrm{a}}$ & $4.9^{\mathrm{a}}$ & $3.9^{\mathrm{ab}}$ & $20.1^{a}$ & $5.5^{\mathrm{ab}}$ & $5.2^{\mathrm{a}}$ & $5.0^{\mathrm{a}}$ & $4.2^{\mathrm{a}}$ & $19.9^{a}$ \\
\hline $\mathrm{RRA}+\mathrm{SB}$ & $5.9^{\mathrm{a}}$ & $5.5^{\mathrm{a}}$ & $4.4^{\mathrm{a}}$ & $3.6^{\mathrm{ab}}$ & $19.5^{\mathrm{a}}$ & $5.7^{\mathrm{a}}$ & $5.7^{\mathrm{a}}$ & $5.0^{\mathrm{a}}$ & $3.8^{\mathrm{ab}}$ & $20.2^{a}$ \\
\hline$R R A+T F$ & $5.9^{\mathrm{a}}$ & $5.6^{a}$ & $4.7^{\mathrm{a}}$ & $3.3^{b}$ & $19.5^{\mathrm{a}}$ & $5.6^{\mathrm{ab}}$ & $5.2^{\mathrm{a}}$ & $4.6^{\mathrm{ab}}$ & $4.0^{\mathrm{ab}}$ & $19.4^{\mathrm{a}}$ \\
\hline$A+S B+T F$ & $6.0^{\mathrm{a}}$ & $5.4^{\mathrm{a}}$ & $5.1^{a}$ & $3.8^{\mathrm{ab}}$ & $20.3^{\mathrm{a}}$ & $5.9^{a}$ & $5.2^{\mathrm{a}}$ & $5.2^{\mathrm{a}}$ & $4.0^{\mathrm{ab}}$ & $20.3^{\mathrm{a}}$ \\
\hline $\mathrm{LLA}+\mathrm{SB}+\mathrm{TF}$ & $5.8^{\mathrm{a}}$ & $5.4^{\mathrm{a}}$ & $4.7^{\mathrm{a}}$ & $3.6^{\mathrm{ab}}$ & $19.5^{\mathrm{a}}$ & $5.3^{\mathrm{ab}}$ & $5.2^{\mathrm{a}}$ & $4.7^{\mathrm{ab}}$ & $3.8^{\mathrm{ab}}$ & $19.0^{\mathrm{a}}$ \\
\hline $\mathrm{RRA}+\mathrm{SB}+\mathrm{TF}$ & $5.5^{\mathrm{a}}$ & $5.6^{\mathrm{a}}$ & $4.6^{\mathrm{a}}$ & $3.6^{\mathrm{ab}}$ & $19.3^{\mathrm{a}}$ & $5.7^{\mathrm{a}}$ & $5.3^{\mathrm{a}}$ & $4.7^{\mathrm{ab}}$ & $4.2^{\mathrm{a}}$ & $19.9^{a}$ \\
\hline \multicolumn{11}{|l|}{$p$-value } \\
\hline $\mathrm{N}$ & 0.0016 & 0.0347 & 0.8406 & 0.0084 & $<.0001$ & 0.051 & 0.8537 & 0.0495 & 0.145 & $<.0001$ \\
\hline $\mathrm{T}$ & $<.0001$ & $<.0001$ & 0.7919 & 0.0315 & $<.0001$ & 0.0057 & 0.2185 & 0.0075 & $<.0001$ & $<.0001$ \\
\hline
\end{tabular}

${ }^{11}$ The LSMEANS with same letter are not significantly different at $p$-value of 0.05 level.

N0, control without fertilizer; N112, nitrogen application $112 \mathrm{~kg} / \mathrm{ha}$; A, gunner conventional alfalfa; LLA, low-lignin Hi-Gest 360 LL alfalfa; RRA, roundup ready RR tonica alfalfa; SB, smooth bromegrass; N/A, not applicable; TF, tall fescue; N, nitrogen fertilizer; $\mathrm{T}$, treatment. 
and without $4.7 \mathrm{Mg} / \mathrm{ha}$ ).

In third cut in 2016, there was no statistical difference in DMY across treatments and fertilizer applications. The DMY of the fourth cut 2016 was significantly higher in the smooth bromegrass plots than in RRA + TF. No difference in DMY was found in different alfalfa varieties and two cool-season grasses. Also, the DMY with nitrogen application treatment was significantly greater than that of the control.

The DMY of smooth bromegrass in the first cut in 2017 was significantly lower than the following combinations: Roundup Ready alfalfa with smooth bromegrass; Gunner alfalfa with smooth bromegrass and tall fescue; and Roundup Ready alfalfa with smooth bromegrass and tall fescue (Table 3). No significant differences were found in DMY among forage species due to nitrogen application. In general, in the third cut of 2017, the DMY of most combinations was higher than that of the smooth bromegrass. No DMY difference was found in alfalfa monocultures and alfalfa-grass mixtures. The DMY was significantly higher with nitrogen fertilizer application than control. Similar results were found in the fourth cut in 2017 where DMY was significantly higher in alfalfa monoculture varieties and legume-grass mixtures than in smooth bromegrass. Unlike the fourth cutting in 2016, there was no significant difference in DMY with nitrogen application in the fourth cutting in 2017.

The possibility of legume-grass mixtures in improving forage quality and increasing DMY over grass monocultures has been studied by many people [8,30,31]. In general, results show that legume-grass mixtures provide higher DMY compared to grass monoculture stands [11]. In both years of this study (2016 and 2017), DMY of alfalfa monocultures and alfalfa-grass mixtures were significantly higher than DMY of monoculture grasses. Unexpectedly, the DMY of alfalfa in monocultures was not significantly different from that of alfalfa in mixtures with grasses. But the alfalfa grass binary mixture has several advantages such as higher total forage yield obtained in the establishment year, faster drying, more digestible fiber, less winter kill, less weed pressure and improved seasonal forage distribution than alfalfa and grass monoculture [32,33]. The monocultures of smooth bromegrass and tall fescue had the lowest biomass of all treatment (Table 3). Sleugh et al. [8], Mortenson et al. [34], and Rao et al. [35] observed that planting grasses with legumes increases yield and availability of nitrogen in the soil. Our results do agree with those of Kopp et al. [7], who found that applying nitrogen fertilizer at a rate of 68 to $110 \mathrm{~kg} /$ haimproved forage production by $64 \%$. Nitrogen application increased the total yield but did not improve the yield significantly in each treatment of our study. In both years, the total yield was significantly higher with nitrogen application than without (with nitrogen in 2016 DMY: $19.2 \mathrm{Mg} / \mathrm{ha}$, in 2017 DMY: $19.8 \mathrm{Mg} / \mathrm{ha}$; without in 2016 DMY: $18.0 \mathrm{Mg} / \mathrm{ha}$, in $2017 \mathrm{DMY}: 18.9 \mathrm{Mg} / \mathrm{ha}$ ) (Table 3).

\section{Forage nutritive values}

\section{Crude protein}

The means CP concentration of each cut in 2016 and 2017 are shown in Table 4 where $\mathrm{CP}$ was found from 65 to $199 \mathrm{~g} / \mathrm{kg}$ dry matter (DM). In all cuts of both years, there was no interaction between species treatments and fertilizer applications for $\mathrm{CP}$.

The CP concentration in the first cut in 2016 was significantly lower in grasses monoculture than in alfalfa monoculture and alfalfa-grass mixtures except the mixture of conventional Gunner alfalfa with smooth bromegrass. In the second cut and third cut of 2016 no significant differences in $\mathrm{CP}$ concentration among treatments was found. When we harvested the smooth bromegrass and tall fescue in the fourth cut in 2016, we found the significantly lower CP concentration in both grasses. The low-lignin alfalfa monoculture had a significantly higher $\mathrm{CP}$ concentration than 
Table 4. Mean CP concentration (g/kg DM) in 2016 and 2017

\begin{tabular}{|c|c|c|c|c|c|c|c|c|c|c|}
\hline \multirow{2}{*}{ Treatments } & \multicolumn{5}{|c|}{2016} & \multicolumn{5}{|c|}{2017} \\
\hline & Cut 1 & Cut 2 & Cut 3 & Cut 4 & Average & Cut1 & Cut 2 & Cut 3 & Cut 4 & Average \\
\hline No & $170^{a 1)}$ & $127^{\mathrm{a}}$ & $126^{\mathrm{a}}$ & $140^{\mathrm{a}}$ & $141^{\mathrm{a}}$ & $137^{\mathrm{a}}$ & $163^{\mathrm{a}}$ & $143^{\mathrm{a}}$ & $141^{a}$ & $145^{\mathrm{a}}$ \\
\hline A & $182^{\mathrm{a}}$ & $129^{\mathrm{a}}$ & $151^{\mathrm{a}}$ & $157^{\mathrm{ab}}$ & $155^{\mathrm{a}}$ & $145^{\mathrm{a}}$ & $163^{\mathrm{a}}$ & $147^{\mathrm{a}}$ & $139^{a}$ & $148^{\mathrm{ab}}$ \\
\hline LLA & $199^{\mathrm{a}}$ & $131^{\mathrm{a}}$ & $151^{\mathrm{a}}$ & $167^{a}$ & $162^{\mathrm{a}}$ & $147^{\mathrm{a}}$ & $158^{a}$ & $139^{\mathrm{a}}$ & $148^{\mathrm{a}}$ & $148^{\mathrm{ab}}$ \\
\hline TF & $132^{c}$ & $111^{\mathrm{a}}$ & $\mathrm{N} / \mathrm{A}$ & $77^{\mathrm{c}}$ & $107^{\mathrm{b}}$ & $107^{b}$ & $\mathrm{~N} / \mathrm{A}$ & $132^{\mathrm{a}}$ & $135^{\mathrm{a}}$ & $125^{\mathrm{c}}$ \\
\hline$A+S B$ & $162^{\mathrm{abc}}$ & $129^{\mathrm{a}}$ & $149^{\mathrm{a}}$ & $140^{\mathrm{ab}}$ & $145^{\mathrm{a}}$ & $134^{\mathrm{ab}}$ & $153^{\mathrm{a}}$ & $144^{\mathrm{a}}$ & $142^{\mathrm{a}}$ & $143^{a b c}$ \\
\hline$A+T F$ & $173^{\mathrm{ab}}$ & $115^{\mathrm{a}}$ & $148^{\mathrm{a}}$ & $136^{\mathrm{ab}}$ & $143^{\mathrm{a}}$ & $145^{\mathrm{ab}}$ & $152^{\mathrm{a}}$ & $150^{\mathrm{a}}$ & $149^{a}$ & $149^{\mathrm{ab}}$ \\
\hline$L L A+S B$ & $172^{\mathrm{ab}}$ & $131^{a}$ & $155^{\mathrm{a}}$ & $126^{b}$ & $146^{a}$ & $137^{\mathrm{ab}}$ & $164^{\mathrm{a}}$ & $148^{\mathrm{a}}$ & $129^{a}$ & $145^{\mathrm{abc}}$ \\
\hline$A+S B+T F$ & $180^{\mathrm{a}}$ & $133^{a}$ & $148^{\mathrm{a}}$ & $130^{\mathrm{ab}}$ & $148^{\mathrm{a}}$ & $135^{\mathrm{ab}}$ & $160^{\mathrm{a}}$ & $143^{\mathrm{a}}$ & $140^{\mathrm{a}}$ & $145^{\mathrm{abc}}$ \\
\hline$L L A+S B+T F$ & $182^{\mathrm{a}}$ & $137^{\mathrm{a}}$ & $159^{\mathrm{a}}$ & $139^{\mathrm{ab}}$ & $154^{\mathrm{a}}$ & $136^{\mathrm{ab}}$ & $161^{\mathrm{a}}$ & $151^{a}$ & $145^{\mathrm{a}}$ & $148^{\mathrm{ab}}$ \\
\hline $\mathrm{RRA}+\mathrm{SB}+\mathrm{TF}$ & $175^{\mathrm{a}}$ & $126^{a}$ & $147^{\mathrm{a}}$ & $151^{\mathrm{ab}}$ & $150^{\mathrm{a}}$ & $138^{\mathrm{ab}}$ & $165^{\mathrm{a}}$ & $141^{\mathrm{a}}$ & $140^{\mathrm{a}}$ & $146^{\mathrm{abc}}$ \\
\hline \multicolumn{11}{|l|}{$p$-value } \\
\hline $\mathrm{N}$ & 0.1601 & 0.9075 & 0.161 & 0.1486 & 0.8494 & 0.5725 & 0.6211 & 0.3376 & 0.8758 & 0.8709 \\
\hline $\mathrm{T}$ & $<.0001$ & 0.3195 & $<.0001$ & $<.0001$ & $<.0001$ & 0.0075 & 0.535 & 0.6692 & 0.203 & 0.0006 \\
\hline
\end{tabular}

${ }^{11}$ The LSMEANS with same letter are not significantly different at $p$-value of 0.05 level.

CP, crude protein; DM, dry matter; N0, control without fertilizer; N112, nitrogen application $112 \mathrm{~kg} / \mathrm{ha}$; A, gunner conventional alfalfa; LLA, low-lignin Hi-Gest 360 LL alfalfa; RRA, roundup ready $\mathrm{RR}$ tonica alfalfa; $\mathrm{SB}$, smooth bromegrass; N/A, not applicable; TF, tall fescue; $\mathrm{N}$, nitrogen fertilizer; $\mathrm{T}$, treatment.

mixture of low-lignin alfalfa with smooth brome grass. In the first cut of 2017, the tall fescue monoculture had a significantly lower $(107 \mathrm{~g} / \mathrm{kg} \mathrm{DM}) \mathrm{CP}$ concentration than alfalfa monocultures and alfalfa -grass mixture of roundup ready Tonica alfalfa with tall fescue $(149 \mathrm{~g} / \mathrm{kg} \mathrm{DM})$. In the second, third and fourth cuts of 2017, no differences in CP concentration were found, because nitrogen was applied after the second cut, and grasses monoculture did not harvest due to poor regrowth. However, it has been shown that planting alfalfa with grasses in mixtures increases crude protein compared to crude protein in grass monocultures [25], and we agree with this statement, on average, the $\mathrm{CP}$ concentration of alfalfa monocultures and alfalfa-grass mixture treatments was significantly higher than monoculture cool-season-grasses.

Overall, in 2016 and 2017 with the same fertilizer treatment, there were no significant differences in CP with nitrogen fertilizer treatment. On average, the CP was higher in 2017 than in 2016 (CP 80-120 g/kg DM in 2016; CP 125-152 g/ $/ \mathrm{kg}$ DM in 2017). In both years with nitrogen application, there was no difference in $\mathrm{CP}$ between the grasses and other treatments. No significant differences in crude protein were observed between the mixtures and the alfalfa monocultures. Schmidt (1993) saw that change in forage nutritive value could be due to temperature and precipitation variance. In our study, 2017 was much dryer than 2016, and the dryness might have led to an increase in the crude protein in the forage treatments.

\section{Acid detergent fiber}

The concentration of ADF was significantly higher in smooth bromegrass than in alfalfa monocultures in the first cut in 2016, but there were no differences in ADF among the legume- 
Table 5. Mean ADF concentration (g/kg DM) in 2016 and 2017

\begin{tabular}{|c|c|c|c|c|c|c|c|c|c|c|}
\hline \multirow{2}{*}{ Treatments } & \multicolumn{5}{|c|}{2016} & \multicolumn{5}{|c|}{2017} \\
\hline & Cut 1 & Cut 2 & Cut 3 & Cut 4 & Average & Cut1 & Cut 2 & Cut 3 & Cut 4 & Average \\
\hline No & $347^{a *}$ & $406^{a}$ & $392^{\mathrm{a}}$ & $389^{a}$ & $383^{a}$ & $362^{a}$ & $339^{a}$ & $365^{a}$ & $350^{a}$ & $355^{\mathrm{a}}$ \\
\hline N 112 & $34.7^{\mathrm{a}}$ & $405^{a}$ & $381^{a}$ & $395^{\mathrm{a}}$ & $382^{a}$ & $362^{\mathrm{a}}$ & $340^{\mathrm{a}}$ & $360^{\mathrm{a}}$ & $350^{a}$ & $354^{a}$ \\
\hline A & $323^{d}$ & $404^{\mathrm{abc}}$ & $398^{a}$ & $380^{\mathrm{bc}}$ & $376^{\mathrm{ab}}$ & $359^{a}$ & $318^{\mathrm{ab}}$ & $357^{\mathrm{ab}}$ & $354^{\mathrm{ab}}$ & $347^{\mathrm{abc}}$ \\
\hline LLA & $332^{\text {bcd }}$ & $364^{c}$ & $381^{a}$ & $352^{c}$ & $357^{b}$ & $355^{a}$ & $330^{\mathrm{ab}}$ & $335^{b}$ & $312^{c}$ & $333^{c}$ \\
\hline RRA & $329^{c d}$ & $410^{\mathrm{abc}}$ & $398^{a}$ & $386^{a b c}$ & $379^{a b}$ & $347^{a}$ & $309^{b}$ & $377^{a}$ & $357^{\mathrm{ab}}$ & $347^{\mathrm{abc}}$ \\
\hline SB & $367^{a}$ & $390^{a b c}$ & $N / A$ & $401^{\mathrm{ab}}$ & $386^{a}$ & $364^{a}$ & $N / A$ & $371^{\mathrm{ab}}$ & $371^{a}$ & $369^{a}$ \\
\hline TF & $357^{\mathrm{abc}}$ & $379^{\mathrm{bc}}$ & $N / A$ & $398^{\mathrm{ab}}$ & $378^{\mathrm{ab}}$ & $360^{a}$ & $\mathrm{~N} / \mathrm{A}$ & $363^{\mathrm{ab}}$ & $362^{\mathrm{ab}}$ & $361^{a}$ \\
\hline$A+S B$ & $345^{\mathrm{abcd}}$ & $418^{\mathrm{ab}}$ & $390^{\mathrm{a}}$ & $395^{\mathrm{ab}}$ & $387^{\mathrm{ab}}$ & $374^{a}$ & $347^{\mathrm{ab}}$ & $375^{\mathrm{ab}}$ & $352^{\mathrm{ab}}$ & $362^{a}$ \\
\hline$A+T F$ & $349^{\text {abcd }}$ & $431^{a}$ & $374^{\mathrm{a}}$ & $404^{\mathrm{ab}}$ & $390^{\mathrm{a}}$ & $353^{\mathrm{a}}$ & $354^{\mathrm{ab}}$ & $372^{\mathrm{ab}}$ & $353^{\mathrm{ab}}$ & $358^{\mathrm{ab}}$ \\
\hline$L L A+S B$ & $350^{\mathrm{abcd}}$ & $413^{a b c}$ & $374^{a}$ & $379^{\mathrm{bc}}$ & $379^{\mathrm{ab}}$ & $364^{a}$ & $343^{a b}$ & $345^{\mathrm{ab}}$ & $343^{a b c}$ & $349^{a b c}$ \\
\hline $\mathrm{LLA}+\mathrm{TF}$ & $343^{\mathrm{abcd}}$ & $407^{\mathrm{abc}}$ & $373^{\mathrm{a}}$ & $378^{\mathrm{bc}}$ & $375^{\mathrm{ab}}$ & $357^{a}$ & $326^{\mathrm{ab}}$ & $339^{\mathrm{ab}}$ & $330^{\mathrm{bc}}$ & $338^{\mathrm{bc}}$ \\
\hline $\mathrm{RRA}+\mathrm{SB}$ & $348^{\mathrm{abcd}}$ & $407^{\mathrm{abc}}$ & $401^{a}$ & $401^{\mathrm{ab}}$ & $389^{a}$ & $371^{a}$ & $365^{a}$ & $366^{\mathrm{ab}}$ & $342^{\mathrm{abc}}$ & $361^{a}$ \\
\hline$R R A+T F$ & $344^{\mathrm{abcd}}$ & $402^{\mathrm{abc}}$ & $378^{a}$ & $401^{\mathrm{ab}}$ & $381^{\mathrm{ab}}$ & $370^{\mathrm{a}}$ & $338^{\mathrm{ab}}$ & $370^{\mathrm{ab}}$ & $361^{\mathrm{ab}}$ & $360^{\mathrm{a}}$ \\
\hline$A+S B+T F$ & $364^{\mathrm{ab}}$ & $428^{\mathrm{ab}}$ & $388^{a}$ & $417^{a}$ & $400^{a}$ & $376^{a}$ & $361^{\mathrm{ab}}$ & $369^{a b}$ & $356^{\mathrm{ab}}$ & $365^{\mathrm{a}}$ \\
\hline $\mathrm{LLA}+\mathrm{SB}+\mathrm{TF}$ & $350^{\mathrm{abcd}}$ & $402^{\mathrm{abc}}$ & $389^{a}$ & $386^{\mathrm{abc}}$ & $382^{\mathrm{ab}}$ & $357^{\mathrm{a}}$ & $334^{\mathrm{ab}}$ & $358^{\mathrm{ab}}$ & $340^{\mathrm{abc}}$ & $347^{\mathrm{abc}}$ \\
\hline $\mathrm{RRA}+\mathrm{SB}+\mathrm{TF}$ & $354^{\mathrm{abcd}}$ & $417^{\mathrm{abc}}$ & $392^{\mathrm{a}}$ & $409^{\mathrm{ab}}$ & $393^{\mathrm{a}}$ & $358^{\mathrm{a}}$ & $350^{\mathrm{ab}}$ & $376^{\mathrm{ab}}$ & $362^{\mathrm{ab}}$ & $361^{a}$ \\
\hline \multicolumn{11}{|l|}{$p$-value } \\
\hline $\mathrm{N}$ & 0.9838 & 0.8416 & 0.1168 & 0.1327 & 0.5583 & 0.863 & 0.6824 & 0.286 & 0.9835 & 0.6704 \\
\hline $\mathrm{T}$ & 0.0003 & 0.0018 & 0.8074 & $<.0001$ & 0.0005 & 0.5159 & 0.0212 & 0.0032 & $<.0001$ & $<.0001$ \\
\hline
\end{tabular}

The LSMEANS with same letter are not significantly different at $p$-value of 0.05 level.

ADF, acid detergent fiber; DM, dry matter; N0, control without fertilizer; N112, nitrogen application 112 kg/ha; A, gunner conventional alfalfa; LLA, low-lignin Hi-Gest 360 LL alfalfa; RRA, roundup ready RR tonica alfalfa; SB, smooth bromegrass; N/A, not applicable; TF, tall fescue; N, nitrogen fertilizer; T, treatment.

grass mixtures and alfalfa monocultures (Table 5). In the second cut in 2016, the low-lignin alfalfa variety had a significantly lower $\mathrm{ADF}$ content than mixtures alfalfa $(\mathrm{A})+$ smooth brome $(\mathrm{SB})$ and $\mathrm{A}+$ tall fescue $(\mathrm{TF})(364,418$, and $431 \mathrm{~g} / \mathrm{kg} \mathrm{DM})$. Smooth bromegrass and tall fescue were not harvested during the third cut in 2016. No differences in ADF concentration were observed for species treatments in the third cut. In the fourth cut of 2016, ADF content of low lignin alfalfa was significantly lower than grass monocultures and conventional alfalfa with grass mixtures. Nitrogen application had no significant effect on ADF concentration in all cuts.

In the first cut in 2017, no significant differences in ADF concentration among the alfalfa monocultures, grasses, and legume-grass mixtures were observed. In the second cut of 2017, there were no significant differences among treatments, except the Roundup Ready alfalfa had a significantly lower ADF than a mixture of Roundup Ready alfalfa with smooth bromegrass (RRA: $309 \mathrm{~g} / \mathrm{kg}$ DM, RRA + SB: $365 \mathrm{~g} / \mathrm{kg}$ DM). In the third cut in 2017, the reduced-lignin alfalfa variety had significantly lower ADF than the Roundup Ready alfalfa (LLA: $335 \mathrm{~g} / \mathrm{kg}$ DM, RRA: $377 \mathrm{~g} / \mathrm{kgDM}$ ). In the fourth cut of 2017, the low-lignin alfalfa had the lowest ADF (312 $\mathrm{g} / \mathrm{kg} \mathrm{DM})$, and smooth bromegrass had significantly $(p<0.05)$ the highest ADF $(371 \mathrm{~g} / \mathrm{kg} \mathrm{DM})$. Nitrogen fertilizer application did not affect $\mathrm{ADF}$ concentration in all cuts.

Results in our study showed that, on average, ADF was significantly lower in the low-lignin alfalfa in both years than $\mathrm{ADF}$ in pure grasses and alfalfa-grass mixtures. The $\mathrm{ADF}$ concentration is related to the cell wall portion of the plants, which is made up of lignin and cellulose. Digestibility is dependent upon ADF; as ADF concentration increases, the digestibility decreases [36]. Our results also suggest that mixed cropping of alfalfa with other grasses or species may not only increase forage yield compared to grasses in monoculture but also decrease the risk of bloating [37]. 


\section{Neutral detergent fiber}

The NDF concentration in the first cut of 2016 was significantly lower in alfalfa monocultures compared to grasses in monoculture (Table 6). The low-lignin alfalfa variety had the lowest NDF (LLA: $460 \mathrm{~g} / \mathrm{kg}$ DM, SB: $614 \mathrm{~g} / \mathrm{kg}$ DM, TF: $574 \mathrm{~g} / \mathrm{kg}$ DM). No difference in NDF was found in alfalfa-grass mixtures. Nitrogen fertilizer application significantly increased the NDF. With nitrogen application, the NDF was $534 \mathrm{~g} / \mathrm{kgDM}$, and without nitrogen NDF it was $513 \mathrm{~g} / \mathrm{kgDM}$. In the second cut of 2016, tall fescue had a significantly higher NDF than alfalfa in monocultures and alfalfa-grass mixtures. No significant differences were observed due to nitrogen application. In the third cut in 2016, the NDF was significantly lower in the low-lignin alfalfa monoculture than in these mixtures: $\mathrm{A}+\mathrm{SB}, \mathrm{A}+\mathrm{TF}, \mathrm{RRA}+\mathrm{SB}, \mathrm{A}+\mathrm{SB}+\mathrm{TF}$. Nitrogen application had a significant effect on NDF concentration; the mean of NDF was significantly lower with nitrogen than without nitrogen (with nitrogen application NDF: $484 \mathrm{~g} / \mathrm{kg}$ DM, without NDF: $496 \mathrm{~g} / \mathrm{kg} \mathrm{DM}$ ). In the fourth cut of 2016, NDF was significantly higher in grass monocultures than in the other treatment (SB: $588 \mathrm{~g} / \mathrm{kg} \mathrm{DM}, \mathrm{TF}: 585 \mathrm{~g} / \mathrm{kg} \mathrm{DM}$ ). The low-lignin alfalfa had a significantly lower NDF than the grasses and mixtures, except for the mixture low-lignin alfalfa with tall fescue (LLA: $465 \mathrm{~g} / \mathrm{kg}$ DM, LLA + TF: $487 \mathrm{~g} / \mathrm{kg}$ DM). With nitrogen application, NDF was significantly higher than without nitrogen application.

In first cut in 2017, tall fescue had a significantly higher NDF concentration than the other treatments. There were no significant differences due to nitrogen application in all cuts. In the second cut in 2017, no significant differences were observed in NDF among combinations or due to nitrogen application. In the third cut in 2017 , the low-lignin alfalfa variety, the conventional

Table 6. Mean NDF concentration (g/kg DM) in 2016 and 2017

\begin{tabular}{|c|c|c|c|c|c|c|c|c|c|c|}
\hline \multirow{2}{*}{ Treatments } & \multicolumn{5}{|c|}{2016} & \multicolumn{5}{|c|}{2017} \\
\hline & Cut 1 & Cut 2 & Cut 3 & Cut 4 & Average & Cut1 & Cut 2 & Cut 3 & Cut 4 & Average \\
\hline No & $513^{b 1)}$ & $518^{a}$ & $496^{\mathrm{a}}$ & $508^{a}$ & $512^{b}$ & $475^{\mathrm{a}}$ & $411^{a}$ & $465^{\mathrm{a}}$ & $467^{a}$ & $458^{a}$ \\
\hline A & $470^{\text {ef }}$ & $503^{b}$ & $476^{a b}$ & $491^{\mathrm{bc}}$ & $486^{\mathrm{de}}$ & $458^{\mathrm{c}}$ & $396^{\mathrm{a}}$ & $432^{b}$ & $459^{b c}$ & $436^{\text {cde }}$ \\
\hline LLA & $460^{f}$ & $489^{b}$ & $441^{b}$ & $466^{c}$ & $465^{\mathrm{e}}$ & $443^{c}$ & $398^{\mathrm{a}}$ & $422^{b}$ & $412^{d}$ & $419^{e}$ \\
\hline $\mathrm{TF}$ & $574^{\mathrm{ab}}$ & $573^{\mathrm{a}}$ & $\mathrm{N} / \mathrm{A}$ & $608^{\mathrm{a}}$ & $585^{\mathrm{a}}$ & $550^{\mathrm{a}}$ & $\mathrm{N} / \mathrm{A}$ & $518^{\mathrm{a}}$ & $523^{a}$ & $530^{\mathrm{a}}$ \\
\hline$A+S B$ & $528^{\text {bcde }}$ & $512^{b}$ & $508^{\mathrm{a}}$ & $501^{\mathrm{bc}}$ & $513^{\mathrm{cd}}$ & $487^{\mathrm{bc}}$ & $416^{a}$ & $474^{\mathrm{ab}}$ & $483^{\mathrm{abc}}$ & $465^{\mathrm{bc}}$ \\
\hline$A+T F$ & $516^{\text {bcdef }}$ & $549^{a b}$ & $500^{\mathrm{a}}$ & $517^{\mathrm{bc}}$ & $520^{b}$ & $471^{\mathrm{c}}$ & $424^{\mathrm{a}}$ & $463^{\mathrm{ab}}$ & $480^{\mathrm{abc}}$ & $460^{\mathrm{bcd}}$ \\
\hline$L L A+S B$ & $526^{\text {bcdef }}$ & $504^{b}$ & $481^{\mathrm{ab}}$ & $506^{\mathrm{bc}}$ & $504^{\mathrm{bcd}}$ & $445^{c}$ & $395^{\mathrm{a}}$ & $441^{b}$ & $439^{\mathrm{cd}}$ & $430^{\mathrm{de}}$ \\
\hline$A+S B+T F$ & $546^{\mathrm{bc}}$ & $514^{b}$ & $526^{a}$ & $520^{b}$ & $527^{b}$ & $484^{\mathrm{bc}}$ & $420^{\mathrm{a}}$ & $478^{\mathrm{ab}}$ & $487^{\mathrm{ab}}$ & $467^{b}$ \\
\hline $\mathrm{LLA}+\mathrm{SB}+\mathrm{TF}$ & $526^{\text {bcdef }}$ & $498^{b}$ & $493^{\mathrm{ab}}$ & $492^{\mathrm{bc}}$ & $502^{\mathrm{bcd}}$ & $481^{\mathrm{bc}}$ & $420^{a}$ & $459^{\mathrm{ab}}$ & $456^{\mathrm{bcd}}$ & $454^{\mathrm{bcd}}$ \\
\hline $\mathrm{RRA}+\mathrm{SB}+\mathrm{TF}$ & $539^{\mathrm{bc}}$ & $518^{\mathrm{ab}}$ & $510^{\mathrm{ab}}$ & $503^{\mathrm{bc}}$ & $518^{\mathrm{bc}}$ & $486^{\mathrm{bc}}$ & $425^{a}$ & $467^{\mathrm{ab}}$ & $482^{\mathrm{abc}}$ & $465^{\mathrm{bc}}$ \\
\hline \multicolumn{11}{|l|}{$p$-value } \\
\hline $\mathrm{N}$ & 0.000 & 0.535 & 0.044 & 0.159 & 0.022 & 0.410 & 0.303 & 0.857 & 0.186 & 0.219 \\
\hline $\mathrm{T}$ & $<0.000$ & $<.000$ & 0.000 & $<.000$ & $<.0001$ & $<.000$ & 0.042 & $<.000$ & $<.000$ & $<.0001$ \\
\hline
\end{tabular}

${ }^{11}$ The LSMEANS with same letter are not significantly different at $p$-value of 0.05 level.

NDF, neutral detergent fiber; DM, dry matter; N0, control without fertilizer; N112, nitrogen application $112 \mathrm{~kg} / \mathrm{ha}$; A, gunner conventional alfalfa; LLA, low-lignin Hi-Gest 360 LL alfalfa; RRA, roundup ready RR tonica alfalfa; $\mathrm{SB}$, smooth bromegrass; N/A, not applicable; $\mathrm{TF}$, tall fescue; $\mathrm{N}$, nitrogen fertilizer; $\mathrm{T}$, treatment. 
variety, and two mixtures (low-lignin alfalfa with smooth bromegrass and roundup ready alfalfa with tall fescue) had a significantly lower NDF concentration than smooth bromegrass and tall fescue. In the fourth cut, low-lignin alfalfa had the lowest NDF and grasses had the highest NDF (LLA: $413 \mathrm{~g} / \mathrm{kg}$ DM, SB: $522 \mathrm{~g} / \mathrm{kg}$ DM, TF: $523 \mathrm{~g} / \mathrm{kg}$ DM). Nitrogen fertilizer application did not affect NDF.

Based on our average results for 2016 and 2017, the low-lignin alfalfa had the lowest NDF compared to mixtures and pure grasses. When the NDF concentration increases, DMI by animal decreases [38]. A higher fiber concentration usually occurs in grasses than in leguminous plants [39-41]. Planting grasses as a mixture with alfalfa will improve forage nutritive value by reducing the fiber content. Our results showed that the low-lignin alfalfa monoculture had significantly lower $\mathrm{ADF}$ and NDF. Also, some mixtures with low-lignin alfalfa had a relatively lower fiber content, which can be a benefit to the producer.

\section{Relative feed value}

There was no interaction between species treatments and nitrogen fertilizer application in all cuts of both years for RFV (Table 7).

The RFV in the first cut in 2016 was significantly higher in low-lignin alfalfa (LLA: 129) than in grasses (SB: 91, TF: 99), and alfalfa-grass mixtures (A + SB:110, RRA + SB:108, LLA + SB:109, A + SB + TF: 103, RRA + SB + TF: 106, LLA + SB + TF:109). The RFV with nitrogen application was significantly higher than in the control $(113,109)$. In the second cut in 2016, the RFV of reduced-lignin alfalfa was significantly higher than the RFV of tall fescue and a mixture of conventional alfalfa with tall fescue (LLA: 115, TF: 96, A + TF: 94). In the third cut

Table 7. Mean RFV indexes in 2016 and 2017

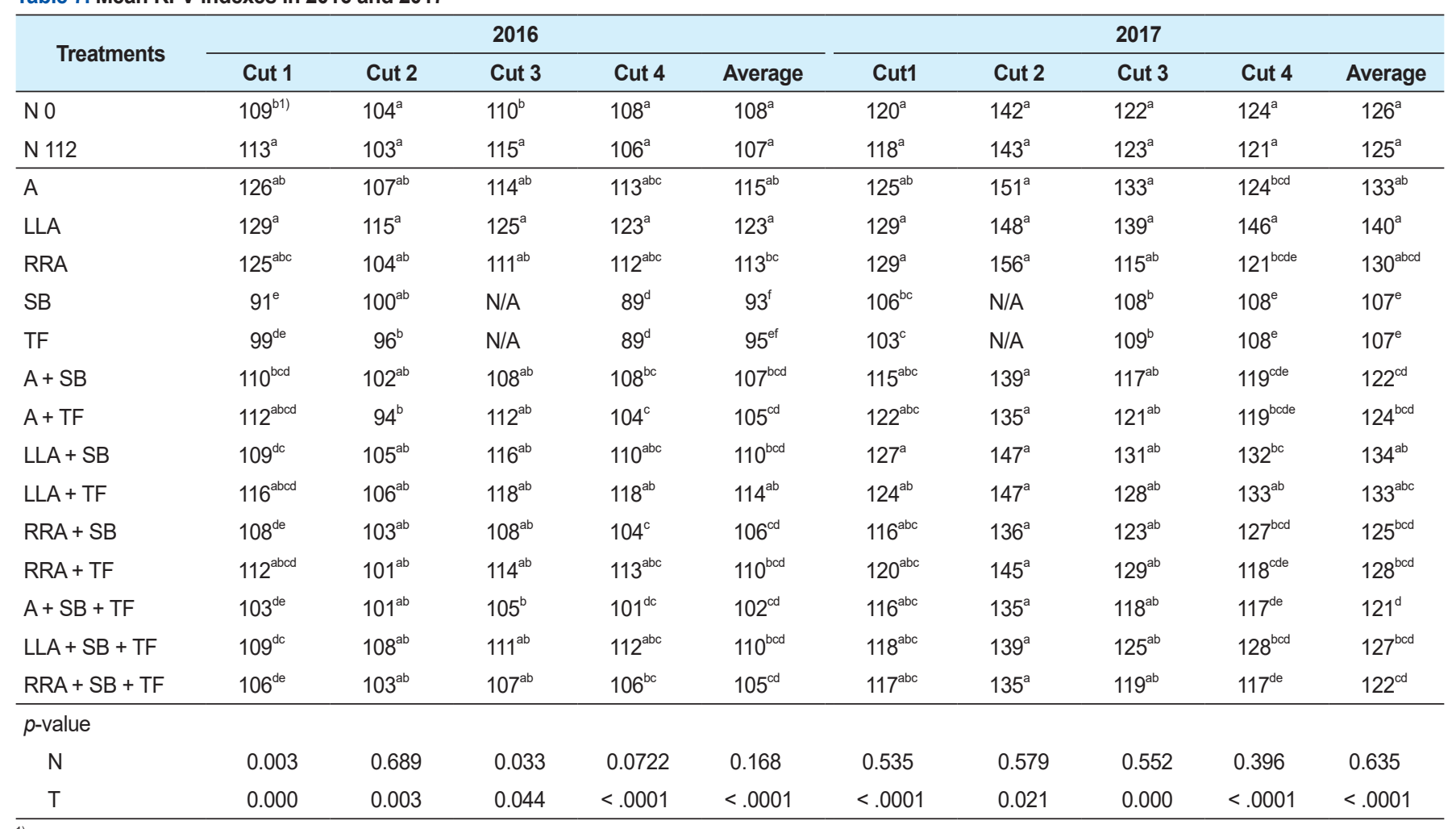

${ }^{1)}$ The LSMEANS with same letter are not significantly different at $p$-value of 0.05 level.

RFV, relative feed value; N0, control without fertilizer; N112, nitrogen application $112 \mathrm{~kg} / \mathrm{ha}$; A, gunner conventional alfalfa; LLA, low-lignin Hi-Gest 360 LL alfalfa; RRA, roundup ready RR tonica alfalfa; SB, smooth bromegrass; N/A, not applicable; TF, tall fescue; N, nitrogen fertilizer; T, treatment. 
in 2016, reduced-lignin alfalfa had a significantly higher RFV value than that of the mixtures of conventional alfalfa with smooth bromegrass and tall fescue (LLA: 125, A + SB + TF: 108). Also, nitrogen application had a significant effect on RFV; RFV was higher with nitrogen than without nitrogen (with nitrogen: 115, without 110). In the fourth cut in 2016, the highest RFV was in the low-lignin alfalfa (123) compared to other treatments. The smooth bromegrass and tall fescue had significantly lower RFV than the other treatments (SB: 89, TF: 89). No significant differences were observed in RFV values due to nitrogen application.

The RFV values in first cut in 2017 were significantly $(p<0.05)$ higher in low-lignin alfalfa, conventional alfalfa, and the mixture of reduced-lignin alfalfa with smooth bromegrass than monocultures of tall fescue and smooth bromegrass (LLA: 129, RRA: 129, LLA + SB: 127, SB: 106, TF: 103). No significant differences in RFV values were observed due to nitrogen fertilizer application.

In the second cut in 2017, no significant difference in RFV values among the treatments and nitrogen application was observed, this was probably due to the smaller portion in alfalfa-grass mixtures grasses, and alfalfa had a larger proportion in the mixtures. In the third cut in 2017, the RFV values were significantly higher in the reduced-lignin alfalfa and the conventional variety of alfalfa than in the smooth bromegrass and tall fescue (A: 133, LLA: 139, SB: 108,TF: 109). In 2017 in the fourth cut, the highest RFV value was in the low-lignin alfalfa and low-lignin alfalfa with tall fescue (LLA: 146, LLA + TF: 133). On average in 2016 and 2017, RFV was highest in LLA and lowest in monocultures of smooth bromegrass and tall fescue. The average RFV in 2016 was 123; in 2017, it was140. The RFV of SB in 2016 was 93 and for TF it was 95. In 2017, the RFV of $\mathrm{SB}$ was 107 and the RFV of TF was 107. In both years, there were no significant differences due to fertilizer application.

\section{CONCLUSION}

The study evaluated the DMY and forage nutritive value of alfalfa-grass mixtures as compared to alfalfa monocultures and grass monocultures for forage production. It also assessed the effect of nitrogen fertilization on dry matter production and forage nutritive value of the different perennial forage species grown in monoculture, in binary mixture, and in trio mixture. According to our study, the forage yields and nutritive value of alfalfa-grass mixtures were higher than monocultures of smooth bromegrass and tall fescue and equal to alfalfa monocultures. All treatments had higher DMY with nitrogen fertilizer application than without nitrogen application. The DMY of the lowlignin alfalfa variety was not significantly different from the DMY of the other two alfalfa varieties (conventional and roundup ready). The lowest forage nutritive value and yield was observed in monocultures of smooth bromegrass and tall fescue. Based on two production year data in 2016 and 2017, the results indicate that planting two most common grasses in Kansas such as smooth bromegrass and tall fescue with legume species such as alfalfa appears to be more desirable practice than monoculture grasses. Also, alfalfa varieties did not affect the DMY indicating that variety selection of alfalfa doesn't appear to affect when alfalfa is being planted with cool-season grasses.

\section{REFERENCES}

1. Barness RF, Nelson CJ, Collins M, Moore KJ. Forages. Volume 1: an introduction to grassland agriculture. 6th ed. Ames, IA: Iowa State University Press; 2003.

2. Lacefield G, Ball D, Hancock D, Andrae J, Smith R. Growing alfalfa in the South. St. Paul, MN: National Alfalfa and Forage Alliance; 2009. 
3. Adhikari L, Missaoui AM. Nodulation response to molybdenum supplementation in alfalfa and its correlation with root and shoot growth in low pH soil.J Plant Nutr. 2017;40:2290-302. https://doi.org/10.1080/01904167.2016.1264601

4. Heichel GH, Henjum KI. Dinitrogen fixation, nitrogen transfer, and productivity of forage legume-grass communities. Crop Sci. 1991;31:202-8. https://doi.org/10.2135/cropsci1991.0011183X003100010045x

5. Malhi SS, Zentner RP, Heier K. Effectiveness of alfalfa in reducing fertilizer $\mathrm{N}$ input for optimum forage yield, protein concentration, returns and energy performance of bromegrass-alfalfa mixtures. Nutr Cycling Agroecosyst. 2002;62:219-27. https://doi.org/10.1023/ A:1021229824357

6. Ta TC Faris MA. Effects of alfalfa proportions and clipping frequencies on timothy-alfalfa mixtures. II. nitrogen fixation and transfer. Agron J. 1987;79:820-4. https://doi.org/10.2134/agr onj1987.00021962007900050013x

7. Kopp JC, McCaugheyWP, Wittenberg KM. Yield, quality and cost effectiveness of using fertilizer and/or alfalfa to improve meadow bromegrass pastures. Can J Anim Sci. 2003;83:291-8. https://doi.org/10.4141/A01-074

8. Sleugh B, Moore KJ, George JR, Brummer EC. Binary legume-grass mixtures improve forage yield, quality, and seasonal distribution. Agron J. 2000;92:24-9. https://doi.org/10.2134/ agronj2000.92124x

9. Sturludóttir E, Brophy C, Bélanger G, Gustavsson AM, Jørgensen M, Lunnan T. Benefits of mixing grasses and legumes for herbage yield and nutritive value in Northern Europe and Canada. Grass Forage Sci. 2014;69:229-40. https://doi.org/10.1111/gfs.12037

10. Waldron BL, Peel MD, Larson SR, Mott IW, Creech JE. Tall fescue forage mass in a grass-legume mixture: predicted efficiency of indirect selection. Euphytica. 2017;213:67. https://doi. org/10.1007/s10681-017-1856-x

11. Albayrak S, Ekiz H. An investigation on the establishment of artificial pasture under ankara's ecological conditions. Turk J Agric For. 2005;29:69-74.

12. Woodfield DR, Clark DA. Do forage legumes have a role in modern dairy farming systems? Irish J Agric Food Res. 2009;48:137-47.

13. Berdahl JD, Karn JF, Hendrickson JR. Dry matter yields of cool-season grass monocultures and grass-alfalfa binary mixtures. Agron J. 2001;93:463-7. https://doi.org/10.2134/ agronj2001.932463x

14. Charles JP, Lehman J. The importance of grass/legume mixtures in forage production in Switzerland. Fourrages. 1989;119:311-20.

15. Cinar S, Hatipoglu R. Forage yield and botanical composition of mixtures of some perennial warm season grasses with alfalfa (Medicago sativa L.) under mediterranean condi. Turk J Field Crops. 2014;19:13-8. https://doi.org/10.17557/tjfc.75994

16. Tracy BF, Albrecht K, Flores J, Hall M, Islam A, Jones G, et al. Evaluation of alfalfa-tall fescue mixtures across multiple environments. Crop Sci. 2016;56:2026-34. https://doi.org/10.2135/ cropsci2015.09.0553

17. Sengul S. Performance of some forage grasses or legumes and their mixtures under dry land conditions. Eur J Agron. 2003;19:401-9. https://doi.org/10.1016/S1161-0301(02)00132-6

18. Rasmussen J, Søegaard K, Pirhofer-Walzl K, Eriksen J. N2-fixation and residual N effect of four legume species and four companion grass species. Eur J Agron. 2012;36:66-74. https://doi. org/10.1016/j.eja.2011.09.003

19. Liu Y, Wu L, Baddeley JA, Watson CA. Models of biological nitrogen fixation of legumes. In: Lichtfouse E, Hamelin M, Navarrete M, Debaeke P, editors. Sustainable agriculture volume 2. 
Dordrecht, Netherlands: Springer; 2011. p. 883-905.

20. Schils RLM, Boxem TJ, Sikkema K, André G. The performance of a white clover based dairy system in comparison with a grass/fertiliser-N system. I. Botanical composition and sward utilisation. NJAS-Wagen J Life Sci. 2000;48:291-303. https://doi.org/10.1016/S15735214(00)80019-6

21. Schils RLM, Boxem TJ, Jagtenberg CJ, Verboon MC. The performance of a white clover based dairy system in comparison with a grass/fertiliser-N system. II. Animal production, economics and environment. NJAS-Wagen J Life Sci. 2000;48:305-18. https://doi.org/10.1016/S15735214(00)80020-2

22. Humphreys J, Casey IA, Laidlaw AS. Comparison of milk production from clover-based and fertilizer-N-based grassland on a clay-loam soil under moist temperate climatic conditions. Irish J Agric Food Res. 2009;48:189-207.

23. Ball DM, Collins M, Lacefield GD, Martin NP, Mertens DA, Olson KE, et al. Understanding forage quality. Park Ridge, IL: American Farm Bureau Federation; 2001. Publication No.: 1-01.

24. Van Saun RJ. Effects of forage quality on a camelid feeding program [Internet]. PennState Extension. 2013 [cited 2020 Aug 4]. https://extension.psu.edu/effects-of-forage-quality-on-acamelid-feeding-program

25. Brown AN, Ferreira G, Teets CL, Thomason WE, Teutsch CD. Nutritional composition and in vitro digestibility of grass and legume winter (cover) crops. J Dairy Sci. 2018;101:2037-47. https://doi.org/10.3168/jds.2017-13260

26. Natural Resources Conservation Service [NRCS]. Web soil survey [Internet]. 2017. [cited 2020 Aug 4]. https://websoilsurvey.sc.egov.usda.gov/App/HomePage.htm

27. Rohweder DA, Barnes RF, Jorgensen N. Proposed hay grading standards based on laboratory analyses for evaluating quality. J Anim Sci. 1978;47:747-59. https://doi.org/10.2527/ jas1978.473747x

28. De Ponti T, Rijk B, Van Ittersum MK. The crop yield gap between organic and conventional agriculture. Agric Syst. 2012;108:1-9. https://doi.org/10.1016/j.agsy.2011.12.004

29. Brennan EB, Boyd NS, Smith RF, Foster P. Comparison of rye and legume-rye cover crop mixtures for vegetable production in California. Agron J. 2011;103:449-63. https://doi. org/10.2134/agronj2010.0152

30. Gierus M, Kleen J, Loges R, Taube F. Forage legume species determine the nutritional quality of binary mixtures with perennial ryegrass in the first production year. Anim Feed Sci Technol. 2012;172:150-61. https://doi.org/10.1016/j.anifeedsci.2011.12.026

31. Guldan SJ, Lauriault LM, Martin CA. Evaluation of irrigated tall fescue-legume communities in the steppe of the southern rocky mountains. Agron J. 2000;92:1189-95. https://doi. org/10.2134/agronj2000.9261189x

32. Aponte A, Samarappuli D, Berti MT. Alfalfa-grass mixtures in comparison to grass and alfalfa monocultures. Agron J. 2019;111:628-38. https://doi.org/10.2134/agronj2017.12.0753

33. Undersander D. Alfalfa grass mixtures. In: Proceedings of the 2012 Wisconsin Crop Management Conference; 2012; Madison, Wi. p. 83-90.

34. Mortenson MC, Schuman GE, Ingram LJ. Carbon sequestration in rangelands interseeded with yellow-flowering alfalfa (Medicago sativa ssp. falcata). Environ Manag. 2004;33:S475-81. https://doi.org/10.1007/s00267-003-9155-9

35. Rao SC, Northup BK, Phillips WA, Mayeux HS. Interseeding novel cool-season annual legumes to improve bermudagrass paddocks. Crop Sci. 2007;47:168-73. https://doi.org/10.2135/ cropsci2006.02.0088

36. Robinson PH, Putnam DH. Interpreting your forage test report. Davis, CA: University of Cal- 
ifornia; 1998.

37. Sottie ET, Acharya SN, McAllister T, Thomas J, Wang Y, Iwaasa A. Alfalfa pasture bloat can be eliminated by intermixing with newly-developed sainfoin population. Agron J. 2014;106:14708. https://doi.org/10.2134/agronj13.0378

38. Jung HJG. Analysis of forage fiber and cell walls in ruminant nutrition. J Nutr. 1997;127:810S3S. https://doi.org/10.1093/jn/127.5.810S

39. Ergon Å, Kirwan L, Bleken MA, Skjelvåg AO, Collins RP, Rognli OA. Species interactions in a grassland mixture under low nitrogen fertilization and two cutting frequencies: 1 . dry-matter yield and dynamics of species composition. Grass Forage Sci. 2016;71:667-82. https://doi. org/10.1111/gfs.12250

40. Fulkerson WJ, Neal JS, Clark CF, Horadagoda A, Nandra KS, Barchia I. Nutritive value of forage species grown in the warm temperate climate of Australia for dairy cows: grasses and legumes. Livestock sci. 2007;107:253-64. https://doi.org/10.1016/j.livsci.2006.09.029

41. Kammes KL, Allen MS. Rates of particle size reduction and passage are faster for legume compared with cool-season grass, resulting in lower rumen fill and less effective fiber. J Dairy Sci. 2012;95:3288-97. https://doi.org/10.3168/jds.2011-5022 